\title{
DOES GOOGLE SERVE AS A MODEL FOR USING PLACE NAMES?
}

Gábor Gercsák, Gábor Mikesy

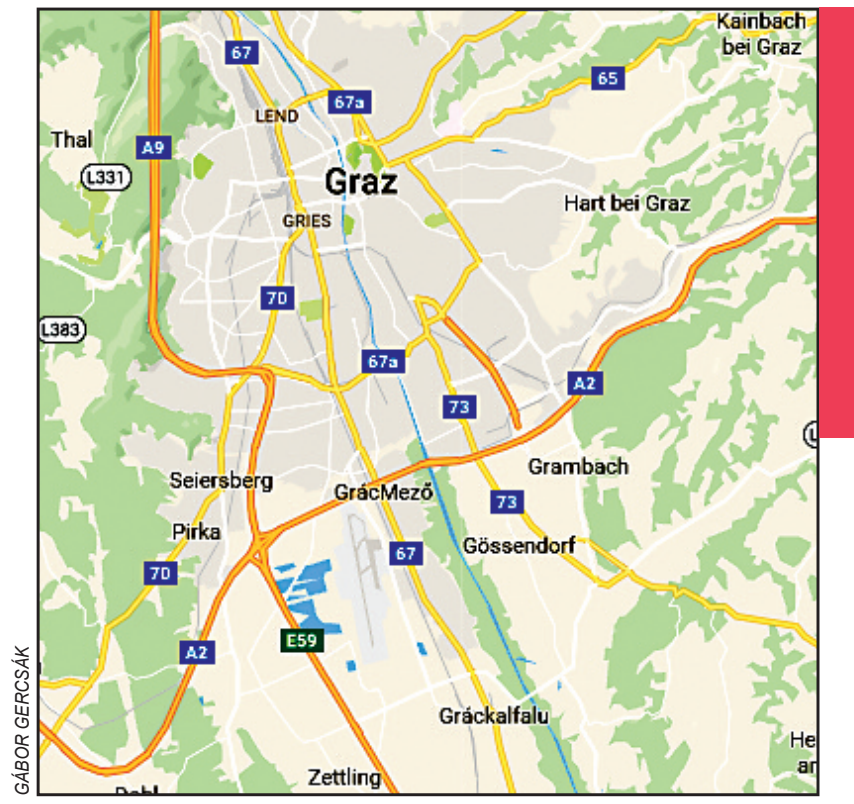

GrácMező instead of Feldkirchen bei Graz. 


\section{Does Google serve as a model for using place names?}

DOI: http://dx.doi.org/10.3986/AGS.4668

UDC: 91:811.511.141'373.21

811.511.141'373.21:004.738.5

\section{COBISS: 1.01}

ABSTRACT: This paper examines the reliability of geographical names published on various internet platforms and seeks to improve the place-name content of internet maps. Hungarian examples of incorrect place names from various online maps draw attention to the need for cooperation between those that provide internet maps or map-based applications and relevant national or professional institutions.

KEY WORDS: geographical name, Hungarian name, place name, toponymy, internet, Google

The article was submitted for publication on August $30^{\text {th }}, 2016$

\section{ADDRESSES:}

Gábor Gercsák, Ph.D.

Department of Cartography and Geoinformatics

Eötvös Loránd University

Pázmány P. s. 1/A, H-1117 Budapest, Hungary

E-mail: gercsak@map.elte.hu

Gábor Mikesy, Ph.D.

Institute of Geodesy, Cartography, and Remote Sensing

Bosnyák tér 5, H-1149 Budapest, Hungary

E-mail: mikesy.gabor@fomi.hu 


\section{Introduction}

Not only have printed maps been losing importance, but several traditional tools that help in correctly understanding and interpreting place names on maps, such as names indexes and legends, also seem to be disappearing from everyday use. In the world of computers, most map users are turning to online methods or mobile applications when they look for any spatial information. This approach has also become the primary source of information for places and place names. Unfortunately, automatic and non-critical acceptance of names from the web is everyday practice; therefore, it is very important that the names available from these sources be reliable and correct in all aspects, including linguistics, science, and administration, and that the names be professionally verified.

\section{Examples of misused place names}

This article presents the most common types of names arranged according to type of mistake. These examples are mostly taken from Google Maps and Google Earth pages and from applications based on them accessed from Hungarian IP addresses. These place names demonstrate a lack of critical use of sources or distortions of names due to various technical reasons. The most common mistakes are missing diacritics, use of historical names without modern equivalents, use of names never approved, false linking of exonyms, and automatic translations of place names.

\subsection{Missing diacritics}

The name of the Hungarian village Kövágószölős appears in the form Kovágószolos (Figure 1), although the correct spellings of all town and village names can be accessed freely and without any restriction (e.g., from the homepage of the Hungarian Central Statistical Office). It is worth mentioning that no other alphabet uses the letter 0 but the Hungarian alphabet.

\subsection{Historical names without modern equivalents}

The name of the capital city of the Italian region Piedmont is unanimously Torino in Hungarian today. This form has been used consistently in the press, schoolbooks, and atlases. Only well-educated people and the older generation with some knowledge of German can match the form Turin (Figure 2) on this Google Earth map with Torino.

Similarly, a major historical site for Hungarians is Rodostó in Turkey, but Tekirdă̆, the Turkish form, has geographical relevance. There are several similar cases. The Croatian town of Opatija has always been a popular holiday resort for Hungarians. Its exonym is Abbázia, which obviously exists for Hungarians,

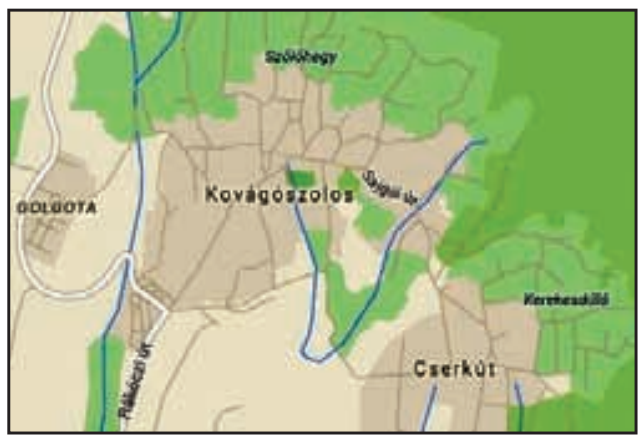

Figure 1: Kővágószőlős with incorrect diacritics. Meanwhile, this mistake has already been corrected on the internet (Internet 1).

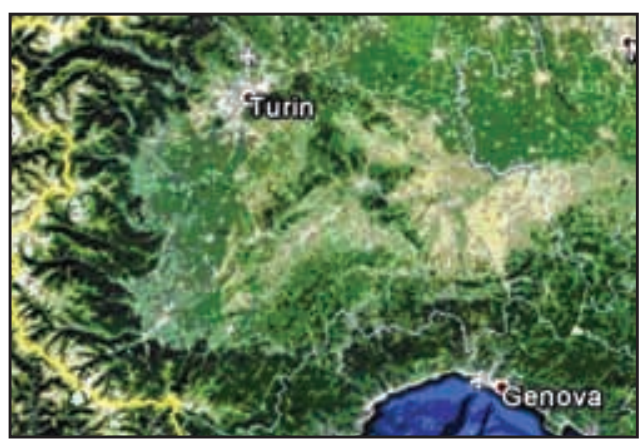

Figure 2: Turin; the old Hungarian form of Torino. This mistake has already been corrected on the internet (GoogleEarth, 4. 10. 2013). 


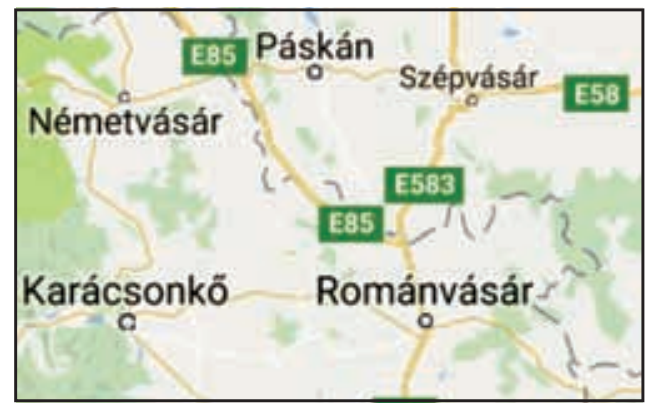

Figure 3: Only historical names in Moldavia (Internet 2).

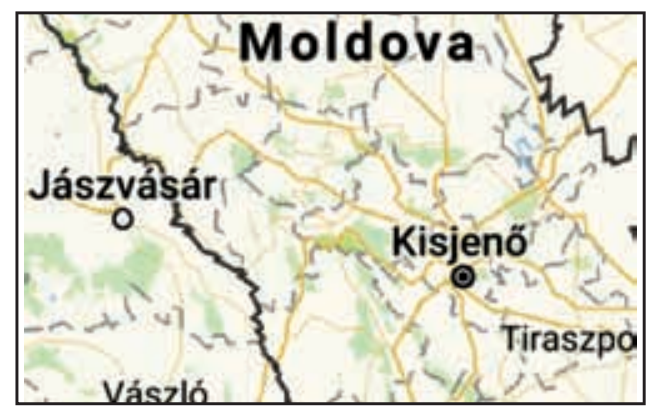

Figure 4: Kisjenő in place of Chişinău (Internet 3).

but is passing out of use (this exonym is not listed in the official catalogue of approved place names; Pokoly 2012). It is interesting to note that some town names that reflect German and Italian influence and belong to the same name type appear in Hungarian (Zára for Zadar and Zengg for Senj), whereas others are shown without their historical exonyms (Raguza, Trau, and Spalato) and only the modern Croatian names appear (Dubrovnik, Trogir, and Split, respectively). These examples demonstrate the inconsistent use of place names.

Hungarian names used in medieval sources are revitalized in those areas of Romania that were outside the territory of historical Hungary (e.g. Karácsonkő for Piatra Neamț, or Németvásár for Târgu Neamț; Figure 3). These forms do not respect the requirement of correct information and they also do not follow the modern use of these geographical names by the Hungarians living in Romania (Mikesy 2014, 219).

It seems that the use of historical names depends on the country concerned. We found that name forms that can be considered either exonyms or historical exonyms are less frequently shown, although their appearance would be much more reasonable for Hungarian readers (e.g. Boroszló for Polish Wrocław, Lemberg for Ukrainian Lviv, Drinápoly for Turkish Edirne, or Spárta for Greek Spárti »Sparta«).

\subsection{Names never approved}

Newly created Hungarian names have begun to appear on online maps (Hlács 2015). Some of them come from false etymologies or incorrect associations. Reliable sources indicate that the Moldovan town of Chişinău never had a Hungarian exonym, although the form Kisjenö (Figure 4) can be seen increasingly frequently today. This name is based on a false etymology.

However, the historically ethnically Hungarian settlement of Kisjenö in Transylvania has an official Romanian name, Chişineu, which is indeed spelled almost in the same way as the name of the capital city of Moldova (Kiss 1987, 230). The Hungarian name comes from the ancient Hungarian tribal name Jenö and the modifier kis »little».

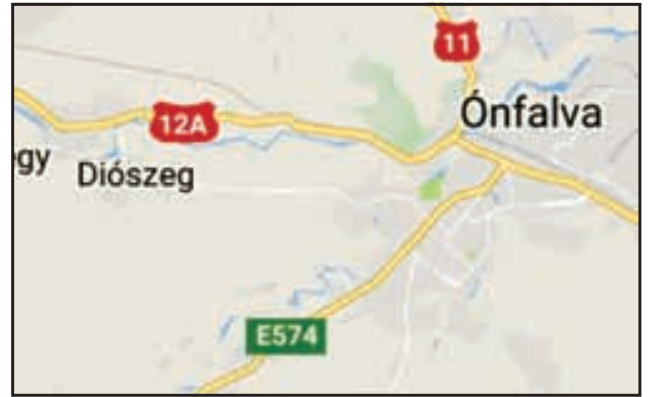

Figure 5: Ónfalva in place of Oneşti/Onyest (Internet 4).

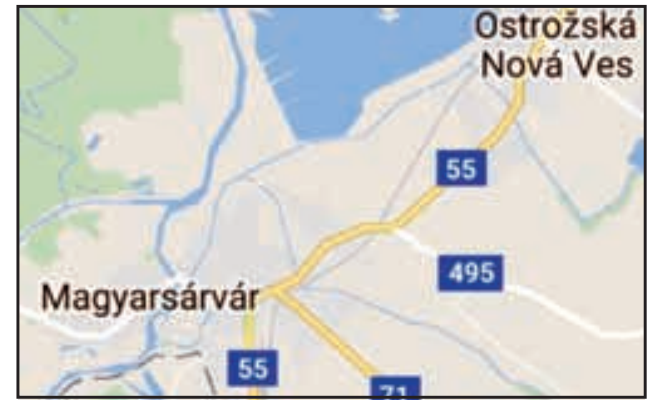

Figure 6: Magyarsárvár in place of Uherský Ostroh (Internet 5). 
The Romanian settlement of Oneşti is a place with a considerable number of Hungarian speakers. Its Hungarian forms Onest and Onyest are justified by old documents. The name Ónfalva (with the meaning "tin village«) appeared in the first half of the past century, but there are no historical or folk data to confirm this name as an exonym (Figure 5). The Hungarian ethnographer Pál Péter Domokos presumed that the first part of Onest includes ón, the Hungarian word for »tin « (Domokos 1987, 179). The new name was developed from this explanation. The renowned etymologist Lajos Kiss derived it from the personal name Ion (Kiss 1988, 746).

The name Magyarsárvár (Figure 6) can be found in place of the Czech settlement Uherský Ostroh. The Czech word uherský means "Hungarian « and relates either to the nearness of the Hungarian border or to the fact that the place was controlled by the king of Hungary for a short time at the end of the fifteenth century. The use of the Hungarian exonym is justified by nothing else than an association based on the meaning. There are no traces of any Hungarian population here or in the area that could have provided the name. The common word ostroh »enclosed place«, »fence« was replaced by Hungarian sárvár "mud castle « because an early medieval chronicle mentions a place called saruuar (Anonymous c. 1200) that might have been located there. However, this name had no any relevance in later documents. The new name is a combination of a vaguely justified anterior constituent and a questionable medieval item.

\subsection{False linking of exonyms}

Urziceni is an important Romanian place north of Bucharest in Ialomița County. Its name on the internet is Csanálos in Hungarian (Figure 7). However, there is a Hungarian village named Csanálos (»nettle place «) near Carei in the Romanian part of the former Hungarian Szatmár County (Figure 8); its name was directly translated into Romanian as Urziceni, which is an officially established name. Because the makers of the electronic map probably had no available sources that would have provided coordinates for the location of Csanálos, they applied it to both places named Urziceni.

A similar mistake was made in the case of two Ukrainian settlements, both named Новоселиия (Novoselytsya). One of them lies in Zakarpattia Oblast, in the area of historical Hungary, and the other in Chernivtsi Oblast. The former settlement has the Hungarian name Taracújfalu; however, it is not shown there (Figure 9) but on the other side of the Carpathian Mountains (Figure 10). The Hungarian name of the place was incorrectly assigned to another place due to their identical forms in Ukrainian.

\subsection{Automatic translations?}

The question mark in the header of this section indicates that the authors can only guess at the reasons for the creation of sometimes comic Hungarian names, which absolutely depart from correct Hungarian place-name practice. These strange names typically appear on the web pages of Austrian and Slovenian territories. For instance, the Austrian name Leitersdorf im Raabtal near Feldbach was replaced by the name Rábakarmestere, which means »conductor of the Rába River «; instead of Raabau one finds Rábaakadálymentes, which roughly means »obstacle-free Rába River (Figure 11); the name Radkersburg/Gornja Radgona on

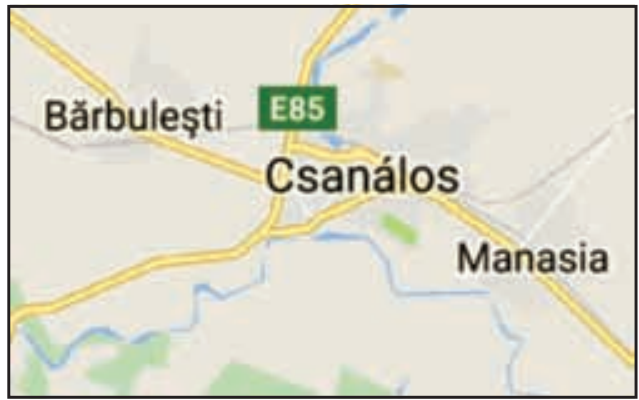

Figure 7: (sanálos in place of Urziceni (Internet 6).

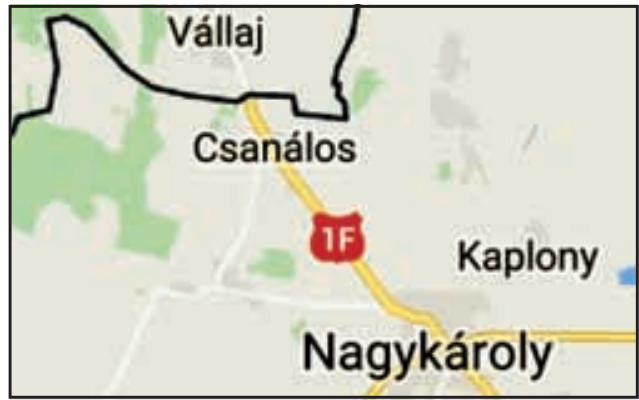

Figure 8: Csanálos in the correct location (Internet 7). 


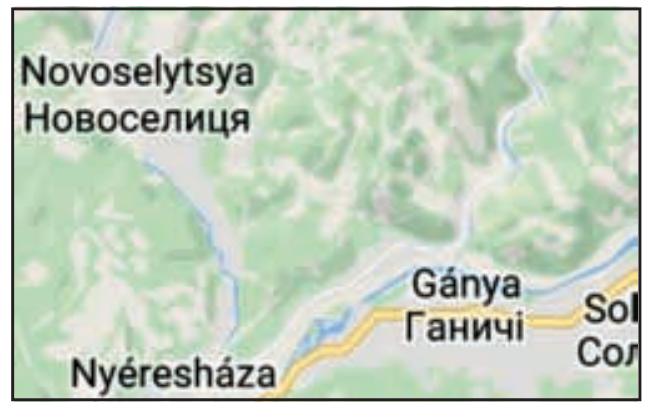

Figure 9: Only the Ukrainian form for Taracújfalu (Internet 8).

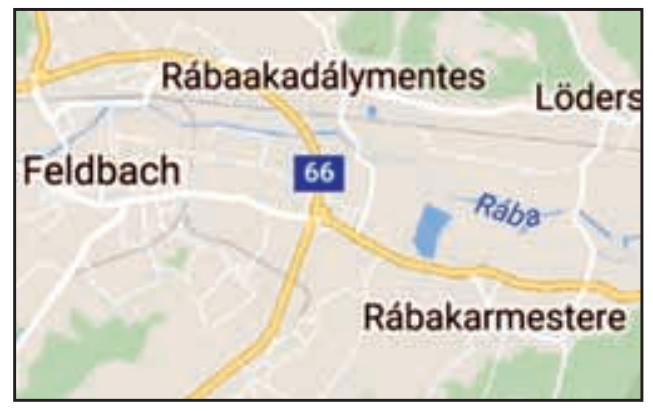

Figure 11: Incorrectnames for Raabau and Leitersdorf im Raabtal (Internet 10).

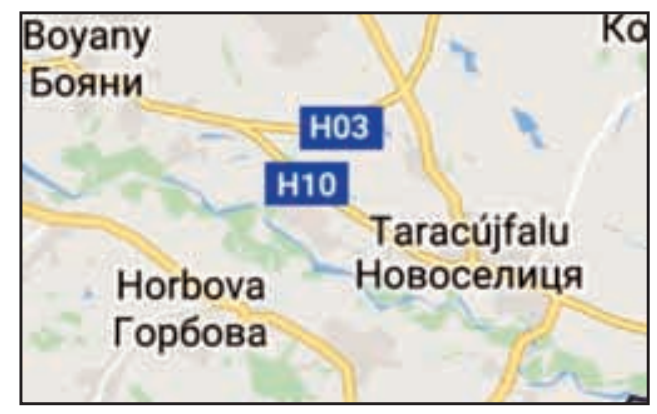

Figure 10: Taracújfalu in the incorrect place (Internet 9).

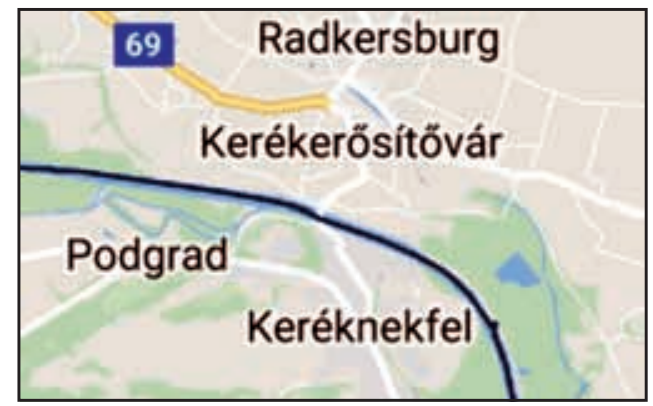

Figure 12: Incorrectnames for Radkersburg and Gornja Radgona (Internet 11).

the Austrian-Slovenian border is translated as Kerékerősitövár (»wheel-strengthening castle«), and the name Podgrad on the Slovenian side is Keréknekfel (»up on the wheel«) in Hungarian (Figure 12).

Another strange example is the Hungarian exonym Élöbecsület (»living honesty «) for the southern Austrian settlement of Ehrenhausen (Figure 13). The meaning of certain elements of the original names can be identified in unjustified Hungarian forms; therefore, it may be presumed that a translation program was active in the background when the Hungarian names were uploaded, and these names were generated by a computer. In any case, a map with this »Hungarian « place name comes up with the hits for Ehrenhausen.

The major problem here is that the names were not checked at all. When we searched for further information on the false names above, it turned out that various applications using computer procedures disseminate these names; for instance, we were able to find offers for transportation services to the "aforementioned « places (Internet 13; Internet 14).

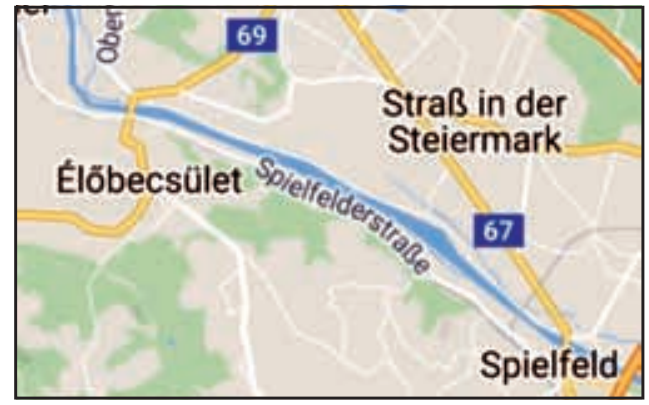




\section{Conclusion}

It is no exaggeration that, based on the examples discussed above, the birth of false geographic names in large numbers in popular media represents a considerable linguistic, cultural, informational, and economic danger, partly because the false names are mixed with relevant data. The authors believe it very important that there should be institutional contact between the responsible geographical name authorities and the developers of online maps. It is advisable to monitor and examine the use of place names on the internet. Geographical name committees and national cartographic services will do the most to disseminate and popularize correct forms of geographic names if they make increasingly more standardized databases of such names freely available on the internet.

\section{References}

Anonymous, cca. 1200: Gesta Hungarorum. Translated by Dezső Pais. Internet: http://mek.oszk.hu/02200/ 02245/02245.pdf (1.8.2016).

Domokos, P. P. 1987: A moldvai magyarság. Budapest.

GoogleEarth (4. 10.2013).

Hlács, F. 2015: Határon túl is magyarít a Google Maps. Internet: http://www.hwsw.hu/hirek/53626/ google-maps-terkep-varosnev-magyar-nyelv.html (26.2.2015).

Internet 1: http://www.magyarorszag-terkep.hu (15.6.2015).

Internet 2: https://www.google.hu/maps/@47.0798939,27.0650687,8z?hl=hu (21.11.2015).

Internet 3: https://www.google.hu/maps/@47.4934968,29.4820609,7z?hl=hu (21.11.2015).

Internet 4: https://www.google.hu/maps/@46.2636311,26.6874137,11z?hl=hu (24.4.2015).

Internet 5: https://www.google.hu/maps/@48.9876058,17.3797622,9332m/data=!3m1!1e3?hl=hu (5.5.2015).

Internet 6: https://www.google.hu/search?q=urziceni\&ie=utf-8\&oe=utf-8\&client=firefox-b\&gfe_rd=cr\&ei= 2u-eV7vWNMjR8gfJl4LgAw (5.5.2015).

Internet 7: https://www.google.hu/maps/@47.6823403,22.4756545,10z (21.11.2015).

Internet 8: https://www.google.hu/maps/@48.1374067,23.7976661,11z?hl=hu (12.5.2015).

Internet 9: https://www.google.hu/maps/@48.2252166,26.2669302,10z?hl=hu (30.4.2015).

Internet 10: https://www.google.hu/maps/@46.9574786,15.9240737,12z?hl=hu (22.11.2015).

Internet 11: https://www.google.hu/maps/@46.6849631,15.9676757,12z?hl=hu (22.9.2015).

Internet 12: https://www.google.hu/search?q=ehrenhausen\&ie=utf-8\&oe=utf-8\&client=firefox-b\&gfe rd=cr\&ei=NS2wV42ECKqo8weX547oCg (22.9.2015).

Internet 13: https://www.google.hu/search?q=ehrenhausen\&ie=utf-8\&oe=utf-8\&client=firefox-b\&gfe $\mathrm{rd}=\mathrm{cr} \& \mathrm{ei}=\mathrm{xOfV} 7 \mathrm{eiIsXR8gfZxY7wDg}(1.9 .2015)$.

Internet 14: http://utitars.oszkar.com/honnan-Ker\%C3\%A9ker\%C5\%91s\%C3\%ADt\%C5\%91v\%C3\%A1r (22.9.2015).

Kiss, L. 1987: Magyar helységnevek a Keleti-Kárpátokon túl. Magyar Nyelvőr 111.

Kiss, L. 1988: Földrajzi nevek etimológiai szótára. Budapest.

Mikesy, G. 2014: Historical, revived or new names? Problems of exonym use from Hungarian toponymic aspects. The Quest for Definitions. Hamburg.

Pokoly, B. 2012: Trends in exonym use: Selected exonyms of the Hungarian language. The Great Toponymic Divide. Warszawa. Internet: http://ksng.gugik.gov.pl/pliki/the_great_toponymi_divide.pdf (1.8.2016). 